\title{
A Close Look At The Driving Forces Of The Sino-Foreign International Joint Ventures
}

Steven X. Si, (E-mail: ssi@bloomu.edu), Bloomsburg University of Pennsylvania Garry D. Bruton, (E-mail: g.bruton@tcu.edu), Texas Christian University

\begin{abstract}
The current study employs measures developed for examining Sino-American international joint ventures (IJV) driving forces in transitional economies. This research reports some significant differences of the IJV factors existing between mature economies and transitional economies. This study also proposes key driving forces to inform a Sino-American IJV in the Chinese context. In addition, the current study explores the degree to which the above factors affect Sino-American IJV establishment in the context of contemporary Chinese conditions.
\end{abstract}

\subsection{Introduction}

$B$ ecause of substantial potential benefits, the international joint venture (IJV) is often seen as an attractive participation strategy for many companies doing business in different countries. However, views regarding the motivations leading toward IJV establishment are diverse. In the past several years, Western academics recognized knowledge learning as one of several different motivations in IJV formation (e.g., Harrigan, 1985; Kogut, 1988; Si \& Bruton, 1999). Only a few studies have focused on this issue in the specific context of an emerging market; rather, most investigations of knowledge learning motivations have focused on IJVs established between firms from mature economies. Knowledge learning in emerging markets is, however, more than just another motivation among a set of equals: much of the world's economic growth will necessarily be generated by emerging markets, and tapping into them will require thorough and specific knowledge of their individual conditions. The current study explores knowledge-learning success issues and the factors affecting knowledgelearning success in Sino-American IJVs.

The literature from a variety of domains tends to suggest that knowledge learning as a motivation for IJV establishment could predominate in firms from emerging economies but not in firms from mature economies: at first glance it is, after all, easier to understand why a firm from an emerging economy would seek to study the organization and methodologies of a successful firm from a mature economy, than to understand what the firm from a mature economy could seek to learn from its more backward partner. Institutional theory, however, argues that in any given locale the institutions impact the strategy of all firms in that region (Scott, 1987, 1995). The institutional environment of any emerging economy is commonly recognized as differing significantly from that of any mature market economy (e.g., Si \& Bruton, 1999). Additionally, resource theory argues that strategic implementation must consider the setting of the firm (Barney \& Zajac, 1994). Strategic management literature argues that there is a need for fit between a firm's strategy and its environment (e.g, Snow \& Miles, 1983). It seems therefore reasonable to state that since the environment of emerging economies is so fundamentally alien, IJVs in such countries established by firms from mature economies may have fundamentally different motivations than IJVs in the developed world comprised of firms from mature economies. Additionally, learning about these great differences in the business environment likely makes knowledge learning by firms from mature economies substantially qualitatively distinct, and quantitatively more important than would be the case in the developed world.

Readers with comments or questions are encouraged to contact the authors via email. 
Several scholars freely admit that our understanding of knowledge learning in IJVs, particularly those set in emerging economies, is limited (e.g., Kogut \& Zander 1992). To date, we have no clear generally accepted statement of the relative importance of knowledge learning as a factor motivating a firm from a mature economy to establish an IJV in an emerging economy; worse yet, we have no generally accepted analysis of what the components of knowledge learning in such a setting might be.

The People's Republic of China (PRC) is the fastest growing emerging economy country in the world. Its size and growth alone constitute understandable economic motivations in the classic sense, as many businesses wish to position themselves to share in the oncoming wealth. Probably as a consequence, the nation also represents the largest IJV market in the world today (United Nations Conference Report, 1994; Bulletin of the Ministry of Foreign Trade and Economic Cooperation of the People's Republic of China 1997). As U.S. firms comprise the largest single block of non-Chinese and non-oriental IJV investors in the PRC, the current study explores the impact of different motivations on U.S. firms in establishing Sino-American IJV in the context of China's emerging economy. Specifically, however, it will focus on the importance of knowledge learning relative to the other motivations proposed by Kogut (1988): transaction costs savings and strategic posturing.

This study will explore key factors affecting knowledge learning in Sino-American IJVs. The resulting information will provide insights into the component parts of knowledge learning as an intangible resource and identify the key factors affecting knowledge learning in an emerging and alien market.

\subsection{Definition}

Joint ventures involve two or more legally distinct organizations (parents), each of which shares in the decision-making activities of a jointly-owned entity (Geringer, 1988). The joint venture is an IJV when at least one parent is headquartered outside the venture's country of operation; therefore, a Sino-Foreign IJV must, by definition, have at least one parent firm headquartered outside of the PRC.

\subsection{Driving Forces To IJV Establishment}

There are a number of factors explaining why IJVs are formed in the literatures. Kogut [1988] attempts to bring greater consistency to analysis of IJV by summarizing the various potential reasons on IJV motivation into three broad categories: knowledge acquisition; transaction costs reduction, and strategic behavior. These motivations for IJV formation have been widely used in the developed countries, but not in the transitional countries such as China. The current study will put a great effort to empirically investigate these IJV motivations in the Chinese context.

\subsection{Transaction Cost}

Transaction cost builds from the initial work by Coarse [1937] and expanded by Williamson [1975, 1985] that focuses on the costs associated with business transactions and the role those costs play in business decisions. An underlying assumption is that firms are economically rational and that they will seek ways to minimize their costs, or transaction costs. Thus if there are ways to save costs by establishing IJV a firm will seek out such a relationship rather than establishing its own business unit.

Firms can reduce the costs of doing business across national borders by internationalizing the production of a given product [Buckley and Casson, 1985]. For example, labor costs may be lower outside the firm's home country base, which motivates the firm to expand internationally. However, there are also costs associated with doing business across national borders such as increased costs of communications, co-ordination, and control [Buckley and Casson, 1976]. Additionally, international transactions also have high levels of uncertainty due to the unknown nature of the local business environment to the local firm [Teece, 1986]. Therefore, it is rational to expect a firm that is expanding internationally to establish an IJV to control these operational costs and uncertainty by bringing in a knowledgeable local firm as a partner [Williamson, 1993]. The operational costs will be lower since the local firm already has individuals on location in the foreign country. Additionally, the local firm's 
understanding of the local market lowers the uncertainty faced by the foreign partner. Even in those situations where the risks remain high the introduction of a partner firm acts to spread the risks between the two firms.

\subsection{Strategic Behavior}

The last category cited by Kogut [1988] recognizes that firms may expand internationally to gain a competitive advantage over its competitors [Lecraw and Morrison, 1993]. Thus in contrast to transaction cost, the principal desired outcome of international efforts by a firm from a strategic behavior perspective is to expand or gain market share, not cost-reduction [Rugman and Verboke, 1992]. Thus, a Western firm establishes an IJV to help overcome constraints, either internal or external, that prevent it from expanding internationally [Contractor and Lorange, 1988]. The focus of the firm in this situation is to gain market share, not to lower costs through greater economies of scale.

\subsection{Knowledge Acquisition}

Knowledge acquisition as a motivation for IJV draws its theoretical support from resource theory. This theoretical perspective argues that if firms' resources are unique, valuable, rare and costly for other firms to develop, they can provide a competitive advantage to the firm [Barney, 1986]. Such resources can develop over time indigenously within the firm [Barney, 1991], or more quickly be obtained through the use of acquisitions or joint ventures [Eisenhardt and Schoonhoven, 1996]. These resources may be of either a tangible or intangible nature [Maijoor and Witteloostuijn, 1996]. Tangible resources are those assets that have physical properties while the intangible assets are without physical properties [Michalisin, Smith, and Kline, 1997]. For example, a joint venture can provide tangible financial resources to a firm [Baum and Oliver, 1991]. The sharing of financial resources can provide a firm a competitive advantage because it reduces their dependence on others outside of the alliance [Ulrich and Barney, 1984]. Intangible resources can also be obtained through an IJV. There are two types of intangible resources that can be obtained, assets and skills [Hall, 1992, 1993]. Intangible resource assets include intellectual property such as patents, trademarks, copyright, and registered designs that may be obtained in an IJV. In contrast, intangible skills represent the know-how of the firm's employees, suppliers, and advisors. In an IJV knowledge acquisition is a motivator when one of the parties targets to obtain the know-how of one of these groups through the partnership. However, employing knowledge acquisition to obtain a competitive advantage is difficult in an IJV. The acquisition of intangible assets such as patents can be negotiated; however, the acquisition of intangible skills can only be obtained through the active participation of the IJV partners [Hall, 1992; Peterick, Brodzinski, Quinn, and Fall, 1999]. For example, the knowledge desired from an IJV is typically obtained through the interaction of the various parties in the relationship [Kogut and Zander, 1993]. However, establishing the nature and quality of such interactions cannot be negotiated but instead develops over time. Importantly however, these intangible skills are the area that the firm most likely can develop into capabilities [Michalisin, Smith, and Kline, 1997] that lead to a competitive advantage [Eisenhardt and Schoonhoven, 1996]. Tangible assets can be copied but the intangible assets are much more difficult for competitors to imitate copy.

There is a wide range of intangible skills on which a firm can obtain knowledge. For example, a firm can learn about manufacturing processes and customers through an IJV [Hamel, Doz, and Prahalad, 1989]. Knowledge acquisition can also include greater understanding about a country and the culture in which the IJV will occur [Inkpen, 1998]. This close relationship between the knowledge learned and firm resources has lead to the argument that resource theory is a knowledge-based perspective of the firm [Conner and Prahalad, 1996].

\subsection{Hypotheses}

Although there are many studies regarding IJV in China, little research has been done to directly investigate the IJV motivations under the Chinese context. Given the limitation of information regarding the motivations of Sino-American IJV, initially it is important to ground this research in the reality of the local environment [Daft and Lewin, 1989]. Without such a rich understanding of the environment, it is difficult to be sure that the investigation is truly examining the topic it is meant to examine [Daft and lewin, 1989]. Therefore, prior to conducting the empirical portion of this research, the authors conducted a series of personal interviews in the PRC. The purpose of 
these interviews was to ensure that Kogut's (1988) classification scheme would be relevant and applicable in an emerging country such as China. These interviews generally supported the relevance of Kogut's [1988] classification scheme for IJV motivation in the PRC's business environment. In order to further statistically test this scheme, it is hypothesized that:

Hypothesis 1: Knowledge acquisition, transaction cost, and strategic positioning are the three major motivation categories that significantly affect the formation of an IJV by United States firms in the PRC.

Hypothesis 2: Due the environment complexity, learning knowledge is the prioritized motivation for United States firms to establish an IJV in the Chinese market.

\subsection{Methodology}

The current study partially adopted the guidelines for generating the appropriate pool of items provided by Churchill (1979). The items should be relevant to the concepts and should exhibit a certain factorial composition. The first step was to generate as many items as possible from a review of the Western and the Chinese literatures. To reduce the number of items into a more usable set, a total of 33 top-level American managers with good knowledge of Chinese management and work experience of Sino-American IJVs were interviewed. After this procedure, a set of potential motivational items was developed based on the above interview information (see table $1)$.

\subsection{Survey}

To test hypotheses in this study, we investigated IJV managers' perceptions of three motivation variables affecting the formation of IJV by United States firms in the PRC. The data was gathered through a survey methodology. The survey was printed was bilingual (English and Chinese), and was administrated to the IJV managers in Shanghai, Beijing and Guangzhou in 2001. Members of the research team contacted the local government officials in the three regions to help distribute the questionnaires to the IJV managers in the three cities. The presence of these officials helped to ensure a full participation by the joint venture managers. The IJV managers were asked to complete and return the questionnaire in a month and each respondent was received a letter of appreciation for completing the survey. The survey included various sections, and the questions used to examine the importance of the motivation items for establishing Sino-US IJVs were composed by three categories. Participants were asked to read the questions of IJV motivations and to rate the extent to which the item was important for motivating the companies investing in an IJV in China. Responses were recorded on a seven-point Likert type scale, $1=$ no importance, $7=$ very strong importance.

\subsection{Participants}

Participants were 105 American managers from 58 Sino-American International Strategic Alliances located in these three cities: Shanghai, Beijing and Guangzhou. Among the participants, 118 managers from the IJVs in Shanghai, 31 managers from the IJVs in Beijing and 36 managers from the IJVs in Guangzhou. Participants averaged 2.1 years of IJV experience. Participants in the survey average age were 38.5 years and principally male $(85 \%)$. The majority of participants had advance education - bachelor degrees or above. In addition, to assess any possible big differences in results among the three cities in the sample dummy coded control variables were employed in the regression equations.

\subsection{Results And Discussions}

The results in table 1 showed that the three factors with 18 items are the principle motivations for the formation of an IJV by United States firms in the Chinese context. A variance inflation factor (VIF) was used to test whether the three motivation categories were independent. The VIF measures how much of the variances of the estimated regression coefficients are inflated as compared to when the independent variables are not linearly related. Cohen and Cohen (1983) suggested that VIFs in excess of 10 indicate problems of multicolinearity. Current 
findings indicate that the VIFs: transaction cost is 6.96, strategic behavior is 7.33 and knowledge acquisition is 7.17. Thus, the factors are not multicolinear. The results also indicated that there were no significant differences across the three cities. As such, the dummy codes for cities were not used in further regression equations.

The study reported the mean and standard deviation of transaction cost (mean=4.15, SD=.98), strategic behavior (mean=4.05, $\mathrm{SD}=1.14$ ), and knowledge acquisition (mean=4.21, $\mathrm{SD}=.92$ ). Thus, knowledge acquisition had a slightly higher mean and a slight lower standard deviation among the three variables. We further analyzed our data using multiple regression analysis. The regression model was significant overall (adjusted $\mathrm{R}^{2}=.455, \mathrm{~F}=5.67$, $\mathrm{p}<.01$ ), all of the three motivation variables significantly affect the formation of an IJV by United States firms in the PRC. The results of the regression also showed knowledge acquisition explaining $22 \%$ of the variance. In addition, the significant level was higher than these of the other two categories of motivations. The results were presented in Table 1. The hypotheses in this study were supported.

There are several limitations of this study, for instance, the IJVs sample in this study was largely focusing on the high technology firms, thus this sample can be taken as representative of partial Sino-American IJVs rather than of all Sino-American IJVs in the current Chinese market. In addition, limitation of cost prevented this study reconsider to select the participants with longer IJV experience. In the current sample, participants averaged 2.1 years of IJV experience, which might be too young to represent the IJV overall in the PRC. Future research should expand this investigation by conducting a longitudinal investigation of the impact of organizational learning for resource building over time. China is a highly competitive environment where rapid changes occur. The ability to build knowledge resources over time and maintain a competitive advantage could be expected to rapidly deteriorate in this environment. A longitudinal investigation of this topic would help answering the question of sustainability of the competitive advantage gained through the development of resources built on knowledge obtained. In addition, the prioritized motivation could vary in accordance with the different ages of IJV, thus a longitudinal investigation could reveal find more accurate information explaining the priorities of IJV motivations at different stages.

\section{References}

1. Barney JB, Zajac E J. 1994. "Competitive Organizational Behavior: Toward an Organizationally-Based Theory of Competitive Advantage." Strategic Management Journal 15: 5-9.

2. Barney J. 1991. "Firm Resources and Sustained Competitive Advantage." Journal of Management 17: 99-120.

3. Barney J B. 1986. "Strategic Factor Markets: Expectations, Luck, and Business Strategy." Management Science 32: 1231-1241.

4. Baum JAC, Oliver C. 1991. "Institutional Linkages and Organizational Mortality." Administrative Science Quarterly 36: 187-218.

5. Beamish PW. 1993. "The Characteristics of Joint Ventures in the People's Republic of China." Journal of International Marketing 1(2): 29-48.

6. Beamish PW. 1988. Multinational Joint Ventures in Developing Countries. New York: Routledge.

7. Boyacigiller N, Adler NJ. 1991. "The Parochial Dinosaur: Organizational Science in Global Context." Academy of Management Review 16: 262-290.

8. Buckely P, Casson M. 1976. The Future of the Multinational Enterprise. Macmillan: Basingstoke.

9. Buckley P, Casson M. 1985. The Economic Theory of the Multinational Enterprise. Basingstoke: Macmillan.

10. Bulletin of the Ministry of Foreign Trade and Economic Cooperation of the People's Republic of China, 1997.

11. Child J, Yuan L. 1996. "Institutional Constraints on Economic Reform: The Case of Investment Decisions in China." Organization Science 7: 60-77.

12. Coarse RH. 1937. "The Nature of the Firm.” Economica New Series IV: 386-405.

13. Cohen J, Cohen P. 1983. Applied Multiple Regression/Correlation Analysis for the Behavioral Sciences. Lawrence Erlbaum: Hillsdale NJ.

14. Conner KR, Prahalad CK. 1996. "A Resource-Based Theory of the Firm: Knowledge Versus Opportunism." Organization Science 7: 477-501.

15. Contractor FJ, Lorange P. 1988. "Why Should Firms Cooperate. In FJ Contractor, P Lorange (eds)." Cooperative Strategies in International Business. Lexington Books: New York.

16. Daft RL, Lewin AY. 1990. "Can Organization Studies Begin to Break out of the Normal Science Straightjacket? An Editorial Essay." Organizational Science 1: 1-10.

17. Eisenhardt KM, Schoonhoven CB. 1996. "Resource-Based View of Strategic Alliance Formation: Strategic and 
Social Effects in Entrepreneurial Firms." Organization Science 7: 136-150.

18. Geringer JM. 1988. Joint Venture Partner Selection: Strategies for Developed Countries. Quarum Books: Westport CT.

19. Hall R. 1992. “The Strategic Analysis of Intangible Resources.” Strategic Management Journal 13: 135-144.

20. Hall R. 1993. "A framework Linking Intangible Resources and Capabilities to Sustainable Competitive Advantage." Strategic Management Journal 14: 607-618.

21. Hamel G, Doz, Y, Prahalad C. 1989. "Collaborate with your Competition and Win." Harvard Business Review January-February: 133-139.

22. Harrigan KR. 1985. Strategies for Joint Ventures. Lexington Books: Lexington MA.

23. Inkpen AC. 1998. "Learning and Knowledge Transfer Through International Strategic Alliances." Academy of Management Executive 12(4): 69-80.

24. Kogut B. 1988. "Joint Ventures: Theoretical and Empirical Perspectives." Strategic Management Journal 9: 319-332.

25. Kogut B, Zander U. 1992. "Knowledge of the Firm, Combinative Capabilities, and the Replication of Technology." Organization Science 3: 383-397.

26. Lecraw D, Morrrison, AJ. 1993. "Introduction: Transnational Corporations and Business Strategy." In D Lecraw, AJ Morison (eds) Transnational Corporations and Business Policy. Routledge: London.

27. Maijoor S. Witteloostuijn AV. 1996. "An Empirical Test of the Resource Based Theory: Strategic Regulation in the Dutch Audit Industry." Strategic Management Journal 17: 549-569.

28. Michalisin MD, Smith, RD, Kline DM. 1997. "In Search of Strategic Assets." The International Journal of Organizational Analysis 5(4): 360-387.

29. Petrick JA., Scherer RF, Broadzinski JD, Quinn JF, Ainina M. 1999. "Global Leadership Skills and Reputational Capital: Intangible Resources for Sustainable Competitive Advantage.” Academy of Management Executive 13(1): 58-69.

30. Rugman A, Verberke A. 1992. "A Note on the Transnational Solution and the Transaction Cost Theory of Multinational Strategic Management.” Journal of International Business Studies 23: 761-771.

31. Scott WR. 1987. “The Adolescence of Institutional Theory.” Administrative Science Quarterly 32: 493-511.

32. Scott WR. 1995. Institutions and Organizations. Age Publications : Thousand Oaks CA:.

33. Si S, Bruton GD. 1999. Knowledge Transfer in International Joint Ventures in Transitional Economies: The China Experience. Academy of Management Executive 13(1): 83-90.

34. Snow CC, Miles RE. 1983. "The Role of Strategy in the Development of a General Theory of Organizations." In R. Lamb (Ed.) Advances in Strategic Management vol. 2: 231-259. JAI Press: Greenwich CT.

35. Teece D. 1986. "Transaction Cost Economics and the Multinational Enterprise." Journal of Economic Behaviour and Organisation 7(1): 21-45.

36. Ulrich D., Barney JB. 1984. "Perspectives in Organizations: Resource Dependence, Efficiency, and Population." Academy of Management Review 9: 471-481.

37. Williamson O. 1985. Modern Institutions of Capitalism. The Free Press: New York.

38. Williamson O. 1993. "Comparative Economic Organisation." In S. Lindenberg and H. Schieuder (eds) Interdisciplinary Perspectives on Organisation Studies. Pergamon Press: Oxford.

39. United Nations Conference Report, 1994.

Steven X. Si is an associate professor of management at the department of management of Bloomsburg University of Pennsylvania. His teaching and research interests include strategic management, strategic human resource management and international business. He has published in the Academy of Management Executive, Journal of Applied Psychology and another peer reviewed academic journals.

Garry D. Bruton is an associate professor of management at the M.J. Neeley School of Business Texas Christian University. His teaching and research interests include strategic management, entrepreneurship and international business. He has published in the Academy of Management Executive, Academy of Management Journal and another peer reviewed academic journals. 
Table 1

Regression Analysis

\begin{tabular}{|c|c|c|c|c|}
\hline \multicolumn{2}{|c|}{ Motivations } & $\beta$ & $\Delta \mathbf{R}^{2}$ & Significance \\
\hline \multicolumn{5}{|c|}{ Knowledge Acquisition: } \\
\hline KA1: & $\begin{array}{l}\text { Gain knowledge of success in a transitional } \\
\text { economy }\end{array}$ & .21 & & $* *$ \\
\hline KA2: & Uncertainty and risk reduction & .20 & & $* *$ \\
\hline KA3: & Acquire useful local knowledge & .25 & & $* * *$ \\
\hline KA4: & $\begin{array}{l}\text { Knowledge for overcoming government-related } \\
\text { barriers }\end{array}$ & .27 & & $* * *$ \\
\hline KA5: & Gain knowledge of the Chinese market & .23 & & $* *$ \\
\hline \multirow[t]{2}{*}{ KA6: } & $\begin{array}{l}\text { Gain knowledge of guanxi, culture and } \\
\text { institutions }\end{array}$ & .25 & & $* * *$ \\
\hline & & & $\left(\mathrm{F}=3.85^{* *}\right)$ & \\
\hline \multicolumn{5}{|c|}{ Transaction Cost: } \\
\hline TC1: & Technology transfer with low cost & .22 & & $* *$ \\
\hline TC2: & $\begin{array}{l}\text { Cooperate and avoid competition, which might } \\
\text { incur greater costs than are incurred by agreeing } \\
\text { to the international joint venture. }\end{array}$ & .10 & & n.s. \\
\hline TC3: & $\begin{array}{l}\text { Create greater market power by combining } \\
\text { resources with some other companies and } \\
\text { create economies of scale. }\end{array}$ & .23 & & $* *$ \\
\hline TC4: & $\begin{array}{l}\text { Facilitating initial international expansion of } \\
\text { inexperienced firms. }\end{array}$ & .21 & & $* *$ \\
\hline TC5: & Gain entry to new market with low total cost & .25 & & $* * *$ \\
\hline \multirow[t]{2}{*}{ TC6: } & Establish a new company with low transaction cost & .23 & & $* *$ \\
\hline & & & $(\mathrm{F}=2.31 *)$ & \\
\hline \multicolumn{5}{|c|}{ Strategic Behavior: } \\
\hline SB1: & Long-term competitiveness positioning & .22 & & $* *$ \\
\hline SB2: & International diversification. & .19 & & $*$ \\
\hline SB3: & Positioning and barriers to competitors & .20 & & $* *$ \\
\hline SB4: & Increase firms' resources and capabilities & .21 & & $* *$ \\
\hline SB5: & Pursue global strategic success & .25 & & $* * *$ \\
\hline SB6: & Pursue international diversification success & .16 & $\left(\mathrm{~F}=2.58^{*}\right)$ & n.s \\
\hline $\begin{array}{l}\mathrm{R}^{2}=. \\
\text { Adjust } \\
\mathrm{F}=5.6\end{array}$ & $\mathrm{R}^{2}=.455$ & & & \\
\hline $\begin{array}{l}* \mathrm{P}<.0 \\
* * \mathrm{P}< \\
* * * \mathrm{P}<\end{array}$ & & & & \\
\hline
\end{tabular}


Notes 